\title{
FORAMINIFERA ASSEMBLAGES AS A MARKER OF MUD ERUPTION SOURCE IN CIUYAH, CINIRU - KUNINGAN, WEST JAVA
}

\author{
KUMPULAN FORAMINIFERA SEBAGAI PETUNJUK SUMBER ERUPSI \\ LUMPUR DI CIUYAH, CINIRU - KUNINGAN, JAWA BARAT
}

\section{Vijaya Isnaniawardhani, Faizal Muhamadsyah, Adjat Sudradjat}

Universitas Padjadjaran, Jln. Raya Bandung-Sumedang Km. 21, Jatinangor, Kab. Sumedang 45363

\begin{abstract}
Mud eruptions that rise claystone to sandstone-size fragments, liquid, gas, and heat to the surface have been identified in Ciuyah, Ciniru District, Kuningan. Field observation and sampling were conducted on host rock as well as mud in Ciuyah. Forty-two planktic and forty-two benthic foraminiferal species were identified in rock samples; while $89.28 \%$ of them are recorded in mud samples. Foraminifera contained in claystone and sandstone of Pemali and Halang Formations reveals the age of Middle to Late Miocene. Based on their stratigraphic ranges, planktic foraminifera assemblages in mud represent four age-marker groups, there are: older than Zone N.10 / Middle Miocene (indicated by the appearance of Globorotalia archeomenardii), ranges of Zone N.11 - N.12 / Middle Miocene (marked by the appearance of Globorotalia fohsi lobata and Globorotalia praemenardii), ranges of Zone N.13-N.14 / Middle Miocene (Globorotalia siakensis and Globorotalia mayeri), and ranges of Zone N.15-N.17 / Late Miocene (Globorotalia acostaensis acostaensis and Neogloboquadrina dutertrei dutertrei). Benthic foraminifera can be grouped into outer neritic and bathyal typical
\end{abstract}

Naskah masuk : 11 Oktober 2017

Naskah direvisi : 26 April 2018

Naskah diterima : 30 Oktober 2018

Vijaya Isnaniawardhani

Department of Geoscience, Universitas Padjadjaran Jl. Raya Bandung-Sumedang Km. 21 Sumedang 45363 Email : vijaya.isnania@unpad.ac.id assemblages. That several age-marker planktic foraminifera groups mixing and deep marine typical benthic occurrence in mud samples is produced by reworking process during turbidity sedimentation, as well as erosion and elution of base- and side-rock composed by Pemali and Halang Formations.

Keywords: foraminifera, mud eruption, source, Ciuyah.

ABSTRAK Semburan lumpur yang membawa fragmen-fragmen berukuran batulempung hingga batupasir, cairan, gas dan panas ke permukaan telah teridentifikasi di Ciuyah, Kecamatan Ciniru, Kuningan. Observasi lapangan dan pengambilan sampel dilakukan terhadap batuan induk serta lumpur di Ciuyah dan sekitarnya. Empat puluh dua spesies foraminifera planktik dan empat puluh dua spesies bentik teridentifikasi dalam sampel batuan; dengan 89,28\% di antaranya terekam dalam sampel lumpur. Foraminifera yang terkandung dalam batulempung dan batupasir Formasi Pemali dan Halang menunjukkan umur Miosen Tengah hingga Akhir. Berdasarkan rentang stratigrafinya, kumpulan foraminifera planktik dalam lumpur menunjukkan empat kelompok penanda umur, yaitu: lebih tua dari Zona N.10 / Miosen Tengah (ditunjukkan oleh kehadiran Globorotalia archeomenardii), rentang Zona N.11 - N.12 / Miosen Tengah (ditandai oleh kehadiran Globorotalia fohsi lobata dan Globorotalia praemenardii), rentang Zona N.13 N.14 / Miosen Tengah (Globorotalia siakensis dan Globorotalia mayeri), dan rentang Zona N.15 N.17 / Miosen Akhir (Globorotalia acostaensis acostaensis dan Neogloboquadrina dutertrei dutertrei). Foraminifera bentik dapat dikelompokkan dalam kumpulan neritik luar dan 
batial. Beberapa kelompok penanda umur foraminifera planktik dan kehadiran bentik laut dalam pada lumpur dihasilkan oleh pengerjaan ulang selama sedimentasi turbidit, serta erosi dan elusi batuan dasar dan batuan samping yang tersusun oleh Formasi Pemali dan Halang.

Kata Kunci: foraminifera, semburan lumpur, sumber, Ciuyah.

\section{INTRODUCTION}

Geologically erupted liquefied sediments and clay-size fragments, liquids and gasses to surface created mountain-shaped cone known as mud mountain. In Indonesia, this mountain topographical expression is generally produced by shale and clay eruption (Istadi, et al., 2012). Typically, they are most abundant in tectonic subduction zones, accretionary wedges, and passive margins within deltaic settings, collisional tectonic zones, convergent orogenic belts and active fault systems, fault-related folds, as well as anticline axes. The active structure act as a conduit for deep formation fluids to reach the surface. The eruptions usually appear to be in line with the direction of structures (Mazzini, et al., 2009; Sawolo, et al., 2009; Hochstein and Sudarman, 2010). The eruption of mud was believed to be triggered by massive earthquakes (Mellors, et al., 2007; Kumai and Yamamoto, 2007; Manga, 2007; Walters et al., 2007; Davies et al., 2008). Mud eruption is also generally founded in areas with rapid sedimentation rates of thick deposits, active compressional tectonics, hydrothermal formation and the generation of hydrocarbon at depth (Pitt and Hutchinson, 1982; Milkov, 2000; Mazzini, et al., 2009).

Mud eruptions are common in the northern part of Java and Madura (Satyana and Asnidar, 2008). These activities typically are located at the top of an anticline or along the fault in the area. Bledug Kuwu, Api Kayangan, Pengangson, Pulungan, Kalang Anyar, Gunung Anyar, and Bujel Tasek mud eruptions occur at the top of the anticline. Lusi (Sidoarjo) erupted on the extension of the anticlinal structure, while Sangiran mud eruption occurs at the top of the truncated dome on an upthrown fault block.

Field observation and sampling on erupted materials and host rock are focused in the area between coordinate $-6^{\circ} 59^{\prime} 44.4^{\prime \prime}$ to $-7^{\circ} 4{ }^{\prime} 43.5^{\prime \prime}$ and $108^{\circ} 27^{\prime} 34.4^{\prime \prime}$ to $108^{\circ} 32^{\prime} 55.7^{\prime \prime}$ where mud eruptions are recorded (Figure 1). The study area is occupied by Tertiary sedimentary rock (Pemali and Halang Formations) as well as Quaternary laharic deposits. Pemali Formation (Tmp) consist of monotoneous beds of greyish blue and green globigerina marls; poorly-well bedded, with sparse intercalation of tuffaceous sandstone and greyish blue sandy limestone. Recognized sedimentary structures are parallel lamination, cross bedding, convolute lamination, and ripple marks. Presumably, the age is Early Miocene. Thickness about $900 \mathrm{~m}$. The Gununghurip member of Halang Formation (Tmhg) is compiled by turbidities, comprising mainly andesitic volcanic breccia; intercalated with sandstone, shale, sandy claystone, and polymict conglomerate; commonly grey, and well-bedded. Common sedimentary structures recognized are parallel and graded beddings. Planktonic fossil assemblage in the sandy claystone tends to indicates a Middle Miocene age. Thickness is up to $2400 \mathrm{~m}$.

Halang Formation (Tmph) consist of tuffaceous sandstone, conglomerate, marl, and claystone; andesitic breccia at the lower part. Sandstone mostly wacke. Deposited as turbidites in an upper bathyal zone. Structures commonly recognized in the unit are graded bedding, parallel lamination, convolute lamination, flute-casts, and load casts, suggesting a deposition in an open marine environment by turbidity currents. Locally, foraminifera and mollusc are found. Presumably, a Middle Miocene-Early Pliocene age. Interfingers with the Gununghurip Member of the Halang Formation. Cipedak lahar deposit (Qc) consist of andesitic rocks fragments, embedded in a coarse sand matrix; well consolidated; probably a product of older Careme volcano, exposed along Cipedak River (Kastowo and Suwarna, 1996; Budhitrisna, 1986) (Figure 2).

The four planktic foraminifera biostratigraphic zones are recognized in stratigraphic succession in the study area (Isnaniawardhani, et al., 2015 a,b), in ascending order:

- Not younger than Zone N.11 - N.12

The appearance of Globorotalia fohsi lobata associated with Globorotalia praemenardii in succession of Pemali Formation indicated Zone N11 - N.12 (more than 12.5 million years ago) or Middle Miocene. 


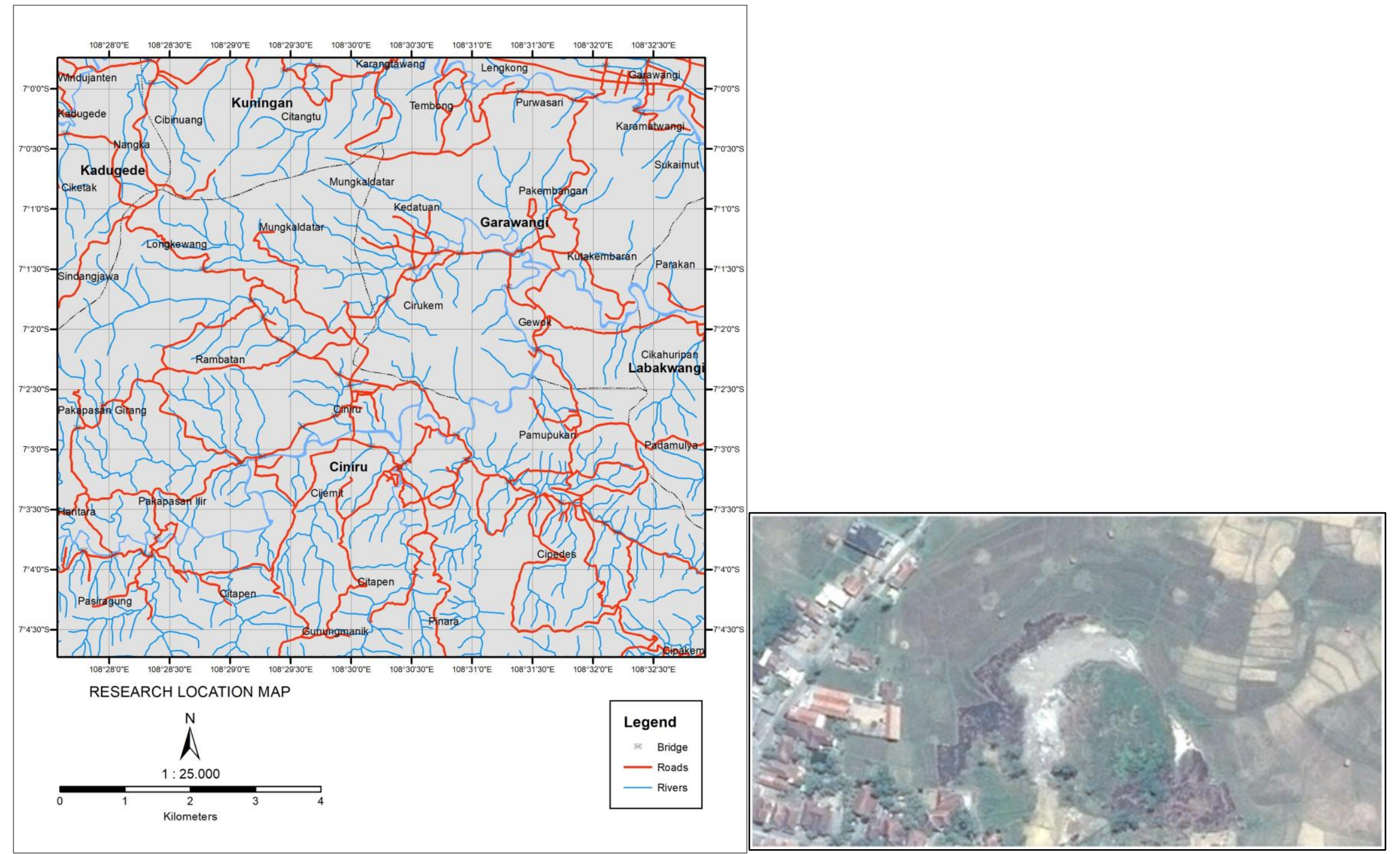

Figure 1. Mud eruption location near Ciremai volcano in the northern part of West Java. 


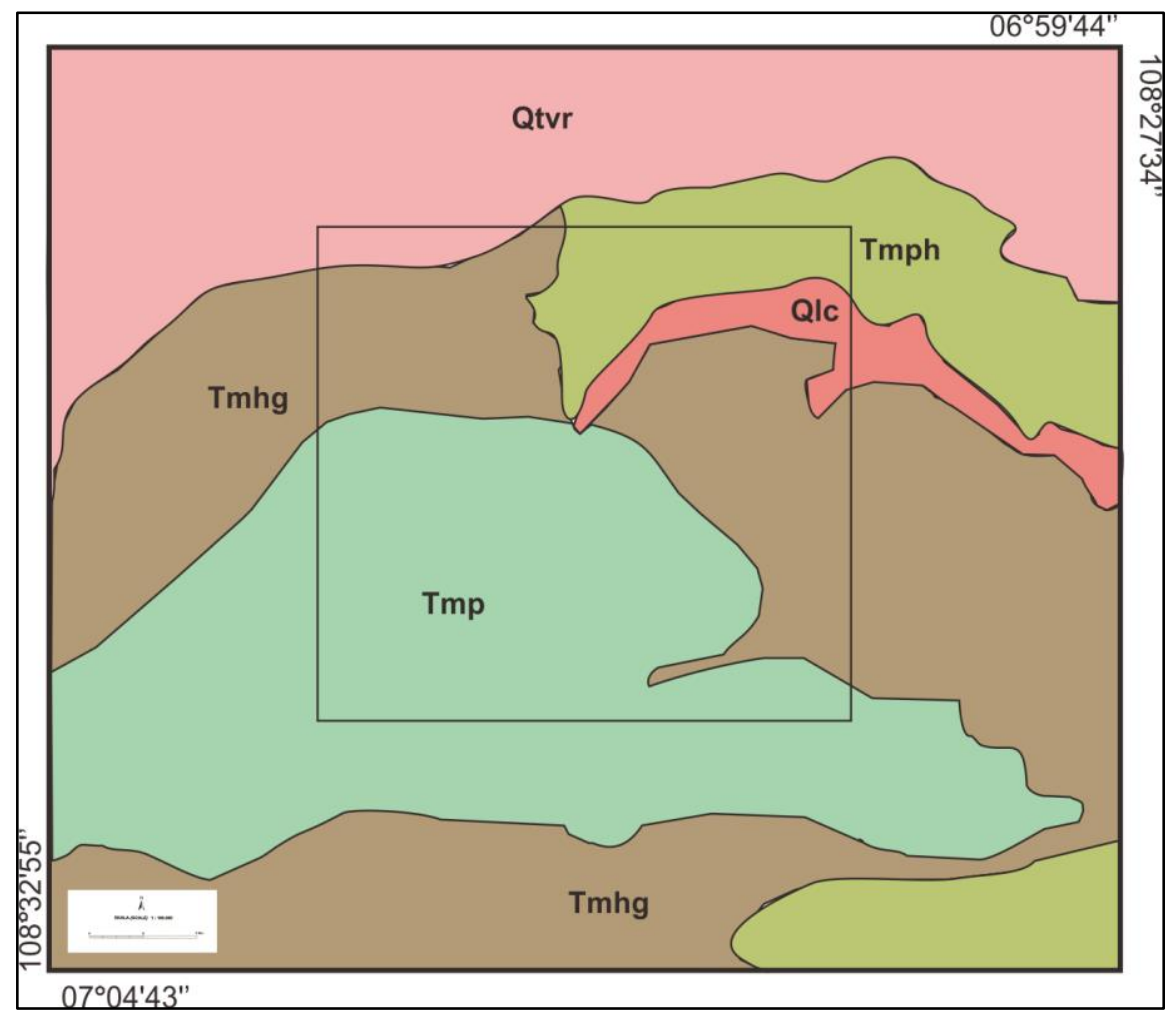

Figure 2. The Miocene strata of Pemali (Tmp) and Halang Formations (Tmhg \& Tmph) overlain unconformably by Quaternary deposits $(\mathrm{Qc})$ in the study area (rectangle).

- Zone N.13 - N.14

The appearance of Sphaerodinellopsis subdehiscens, Globorotalia siakensis, and Globorotalia mayeri associated with Globigerinoides subquadratus, Hastigerina siphonifera and Globorotalia menardii menardii in the lower part of Halang Formation indicated Zone N.13 - N.14 (about more than 11.3 my before present) or Middle Miocene.

- Zone N.15

The appearance of Globigerina nepenthes, Globigerina praebulloides praebulloides, Globorotalia continuosa, Globorotalia menardii menardii, Globorotalia pesudomiocenica, Globigerinoides subquadratus, and Hastigerina aequilateralis in the middle part of Halang Formation indicated Zone N.15 (about 11.3 to $7.1 \mathrm{my}$ BP) or Late Miocene.

- Zone N.16-N.17

The appearance of Globorotalia acostaensis acostaensis, Globorotalia merotumida, Neogloboquadrina dutertrei dutertrei,
Globorotalia humerosa humerosa, Globigerinoides ruber, Candeina nitida, Globigerinoides obliquus extremus and Hastigerina aequiateralis in the upper part of Halang Formation indicated Zone N.16 N.17 (about 7.1 to $5.3 \mathrm{my} \mathrm{BP}$ ) or Late Miocene.

Mud eruption in Ciuyah has been ejected claystone to sandstone-size fragments, liquid, gas, and heat. The sedimentary fragments contain microfossils (foraminifera) which their hard shells are incorporated and preserved in the surrounding sediment. Therefore, the research on foraminifera contents in the ejected material will confirm the source of mud which breaches the earth surface.

Based on the chemical and isotope analysis, it is concluded that fluid drains out from Ciuyah is a formation water originated from the clastic sediments consisting of clay and sandstone. It is also concluded that most likely that Ciuyah water is the result of mixing between formation water and meteoric water flowing from Ciremai hydrologic system. The temperature of water remains stable at $37^{\circ} \mathrm{C}$ both in rainy and dry seasons (Isnaniawardhani, et al., 2018). 


\section{METHODS}

The actual research was done in several stages; was started by the study and collection of secondary data. The geological mapping was taken mainly to identify rock in Ciuyah and its surrounding, as well as mud around eruption area. Fourteen host rocks and nine mud samples are collected to laboratory analysis. In paleontology laboratory, each sample was prepared using hydrogene peroxide to release foraminifera. The residual samples are observed using slab microscope of 40 magnifications. The research adopted some basics methods for identification of foraminifera by Loeblich and Tappan (1988), Bolli and Saunders (1986) and van Marle (1991). Determine stratigraphic age range, as well as biostratigraphic zones, refers to standard zonation of Blow (1969) in Blow (1979), Bolli and Saunders (1986) and Nathan and Leckie (2003).

\section{RESULTS AND DISCUSSION}

\section{The appearance of foraminifera, biostratigraphy and depositional environment of the host rock}

A total of 84 foraminiferal species was identified in outcropped samples in Ciuyah and its surrounding area. Forty-two of them are planktic and forty-two are benthic. Planktic foraminiferal assemblages were identified in host rock samples, consist of:

- fourteen species of genus Globorotalia: $G$. acostaensis acostaensis Blow, $G$. archeomenardii Bolli, G. continuosa Blow, G. fohsi lobata Bermudez, G. humerosa humerosa Takayanagi \& Saito, G. mayeri Cushman \& Ellisor, G. menardii menardii (Parker, Jones \& Brady), G. merotumida Banner \& Blow, G. obesa Bolli, G. opima nana Bolli, G. praemenardii Cushman \& Stainforth, G. pseudomiocenica Bolli \& Bermudez, G. pseudopima Blow and $G$. siakensis (Leroy).

- ten species of genus Globigerinoides: $G$. conglobatus (Brady), G. obliquus extremus Bolli \& Bermudez, G. obliquus obliquus Bolli, G. quadrilobatus (d'Orbigny), G. ruber (d'Orbigny), $G$. sicanus de Stefani, $G$. subquadratus Brommimann, G. trilobus trilobus (Reuss), G. trilobus immaturus LeRoy, and G. trilobus sacculifer (Brady).
- three species of both genera Globigerina, Hastigerina, Orbulina, and Sphaerodinellopsis. Globigerina: $G$. nepenthes Todd, G. praebulloides praebulloides Blow, $G$. venezuelana Hedberg. Hastigerina: $H$. aequilateralis (Brady), $H$. praesiphonifera Blow, $H$. siphonifera (d'Orbigny). Orbulina: $O$. bilobata (d'Orbigny), O. suturalis Bronnimann, $O$. universa d'Orbigny. Sphaerodinellopsis: S. disjuncta (Finlay), $S$. seminulina (Schwager), S. subdehiscens Blow.

- two species of genera Globoquadrina and Neogloboquadrina. Globoquadrina: $G$. altispira altispira (Cushman \& Jarvis), $G$. dehiscens (Chapman, Parr \& Collins). Neogloboquadrina: $N$. dutertrei blowi Rogl \& Bolli, N. dutertrei dutertrei (d'Orbigny).

- each consisting of a species of both genera Candeina and Catapsydrax. Candeina: $C$. nitida d'Orbigny; and Catapsydrax: $C$. dissimilis (Cushman \& Bermudez).

Based on shells composition, benthic foraminifera in rock samples can be grouped to:

- Calcareous shells or Subordo Rotaliina, consist of genera Amphistegina d'Orbigny (A. papilosa, A. radiata), Anomalinella Cushman (A. rostata), Anomalinoides Brotzen (A. globulusus), Bolivina d'Orbigny, Brizalina Costa, Bulimina d'Orbigny, Cassidulina d'Orbigny, Cibicides De Montfort, Duplella Patterson \& Richardson (D. trinalimarginata), Eggrella Cushman, Elphidium De Montfort (E. neosimplex), Eponides De Montfort (E. pusillus), Fiscerinella McCulloch ( $F$. diversa), Fijinonion Hornibrook ( $F$. fijiense), Glandulina d'Orbigny (G. symmetrical), Globocassidulina Voloshinova, Gyroidina d'Orbigny, Hanzawaia Asano $(H$. grossepunctata), Heterolepa Franzenau $(H$. subhaidingeri), Hyalinea Hofker, Hyperammina Brady ( $H$. noavaealandia), Melonis De Montfort, Missipina Felker ( $M$. pacifica), Nodogenerina Cushman ( $N$. lepidula), Nonion De Montfort $(N$. pauperatum), Nummulites Lamarck, Planulina d'Orbigny, Pseudononion Asano (P. granuloumbilicatum), Robulus Montfort, 
Rotalia Lamarck, Stilostomella Guppy and Uvigerina d'Orbigny.

- Porceleneous shells that typified by subordo Miliolina and Lagenina, consist of genera Amphycorina Schlumberger (A. sublineata), Dentalina Risso, Laevidentalina d'Orbigny. (L. bradyensis), Lenticulina Lamarck ( $L$. calcar, L. domantayi), Nodosaria Lamarck, Pyrgo Defrance, Quinqueloculina d'Orbigny (Q. limbata), and Sigmoilina Finlay.

- Arenaceous shells or subordo Textulariina is represented by genera Martinotiella Cushman and Textularia Defrance.

\section{Erupted Materials}

The materials ejected from subsurface are fragments, liquid, gas, and heat (Figure 3). Mud contains claystone, fine to coarse grain sandstone of sedimentary, sub-rounded fine grain calcareous sandstone, sub-rounded fine to coarse grain tuffaceous sandstone, igneous rock and limestone sandstone-size fragments (Isnaniawardhani, et al., 2015b).

The fragments of mud generally contain foraminifera in variety type and amounts of species. Thirty-seven planktic foraminiferal species are recorded from mud samples (Figure 4).

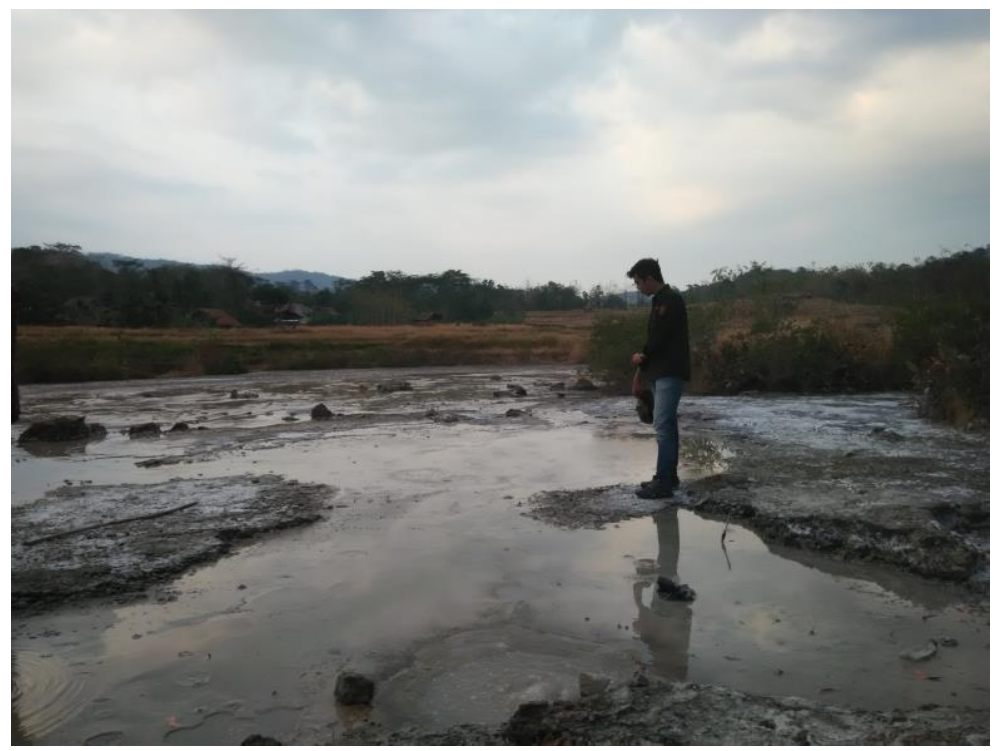

Figure 3. Eruption activity in Ciuyah ejected clay to sandstone-size fragments, fluids, and gasses.

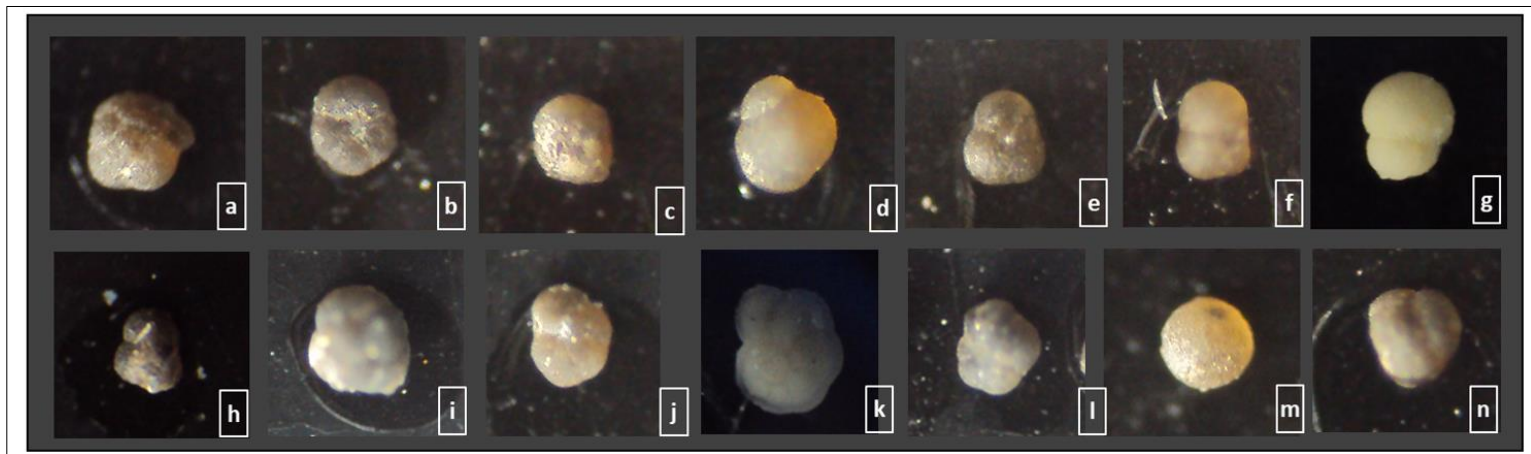

a. Catapsydrax dissimilis, b. Globigerinoides conglobatus, c. Globigerinoides obliquus obliquus d. Globigerinoides quadrilobatus, e. Globigerinoides subquadratus, f. Globigerinoides trilobus immaturus , g. Globogerinoides trilobus trilobus, h. Globigerinoides ruber, i. Globoquadrina altispira altispira, j. Globorotalia mayeri, k. Globorotalia menardii menardii, I. Globorotalia opima nana, m. Orbulina universa, n. Sphaerodinellopsis disjuncta

Figure 4. Planktic foraminifera assemblages in erupted mud originated from host rock (Pemali and Halang Formations). 


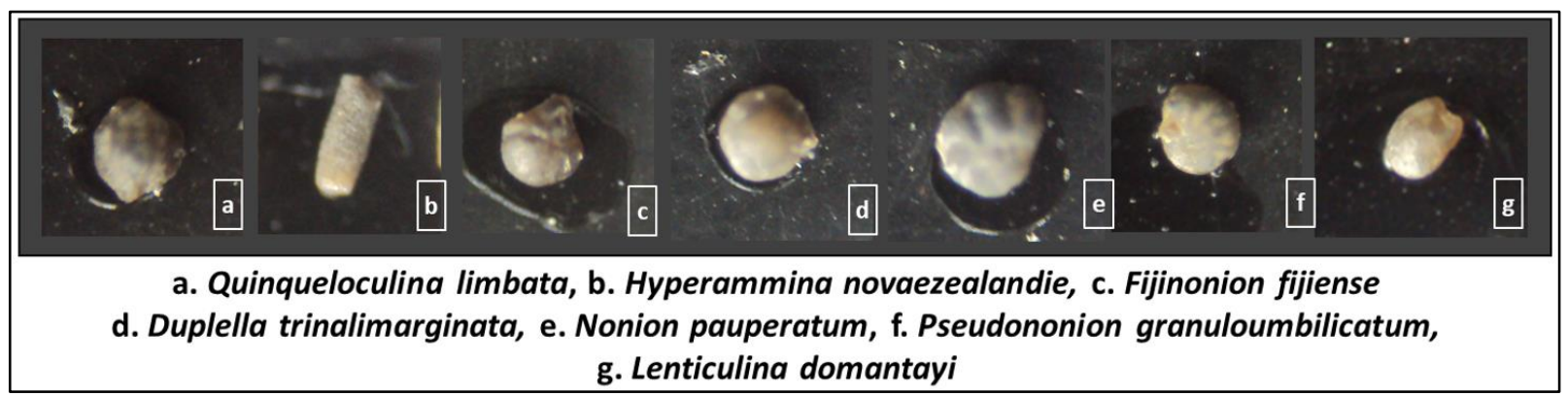

Figure 5. Benthic foraminifera assemblages in erupted mud.

Only four species (4.76\%) are not founded in mud, there are Globorotalia continuosa, $G$. pseudopima, Globigerinoides sicanus, and Hastigerina praesiphonifera. Thirty-eight benthic species can be identified in mud (Figure 3). Amphycorina sublineata, Anomalinella rostata, Fiscerinella diversa, Glandulina symmetrical, Laevidentalina bradyensis, and Missipina pasifica - benthic foram are not recorded in mud (7.14\%).

The mud eruption composes mostly of water, particularly in the wet season. In contrary, in the dry season, very little water drains out from the volcano, resulting in the intensive evaporation of salt travertine. This phenomenon might indicate that water of Ciuyah is also influenced by the meteoric water. It was also reported that the unconfined water at about one kilometer radius in Ciuyah area was saline.

\section{Stratigraphic ranges and depositional environment of foraminifera contained in mud samples}

Based on their stratigraphic ranges (Table 1), planktic foraminifera assemblages represent four age ranges, there are:

- Older than Zone N.10 (more than 16.4 my BP) or lowest of Middle Miocene, indicated by the appearance of Globorotalia archeomenardii. The last appearance of this species is taking place at top of Zone N.10 (Bolli and Saunders, 1984).

- $\quad$ Ranges of Zone N.13 - N.14 (12.5 - 11.3 my BP) or Middle Miocene, indicated by the appearance of Globorotalia siakensis and Globorotalia mayeri. The last appearance of Globorotalia siakensis is used to mark the top of Zone N.14 (Blow, 1969 in Blow, 1979). Bronnimann (1951) in Bolli and Saunders (1986), Nathan and Leckie (2003) mentoined the last appearance of Globorotalia mayeri is taken place at top N.14 or 10.49 my BP.

- $\quad$ Ranges of Zone N.15 - N17 (11.3 - 5.3 my BP) or Late Miocene. The appearance of Globorotalia acostaensis acostaensis, Neogloboquadrina dutertrei dutertrei associated with Candeina nitida, Globigerinoides obliquus extremus, Globigerinoides ruber, and Globorotalia humerosa humerosa reflected a younger group.

Based on the typical environment, benthic foraminifera in mud samples can be grouped to:

- Outer neritic zone, represented by genera Amphistegina, Anomalinoides, Bolivina, Cibicides, Duplella, Elphidium, Eponides, Fijinonion, Heterolepa, Hyalinea, Hyperammina, Nonion, Planulina, Pseudononion, Pyrgo, and Quinqueloculina.

- Bathyal zone, represented by genera Brizalina, Lenticulina, Melonis and Textularia.

Several age-marker foraminifera groups mixing in mud samples is caused by:

- The host rock is deposited by turbidity currents. The appearance of Globorotalia archeomenardii reflected a reworking process during sedimentation caused gravityflow mechanism. As a reworked fossil, this specimen is characterized by damaged or broken shape, scratches on the shells, differences on type and color of closed sediment.

- The ejected material is derived through Pemali and Halang Formations (Figure 6). Lower Middle Miocene aged fossil assemblages are originated from Pemali 
Formation, while Mid-Middle Miocene to Late Miocene aged fossil assemblages from Halang Formation. It is supported by the similarity of species found in both host rock and mud.

The foraminifera assemblages in mud samples are most similar to it assemblages in Middle to Late Miocene sediment (Isnaniawardhani, et al., 2005 a, b) that contained in Pemali and Halang Formations (Kastowo \& Suwarna, 1996 and Budhitrisna, 1996). The thick turbidity sediments succession of these formations are formed in rapid sedimentation rate in the active tectonic area, whereas mud eruption phenomenon usually occurred (Pitt \& Hutchinson, 1982; Milkov, 2000; Mazzini, et al., 2009).

Table 1. Stratigraphic ranges of each planktic foraminifera contained in mud samples.
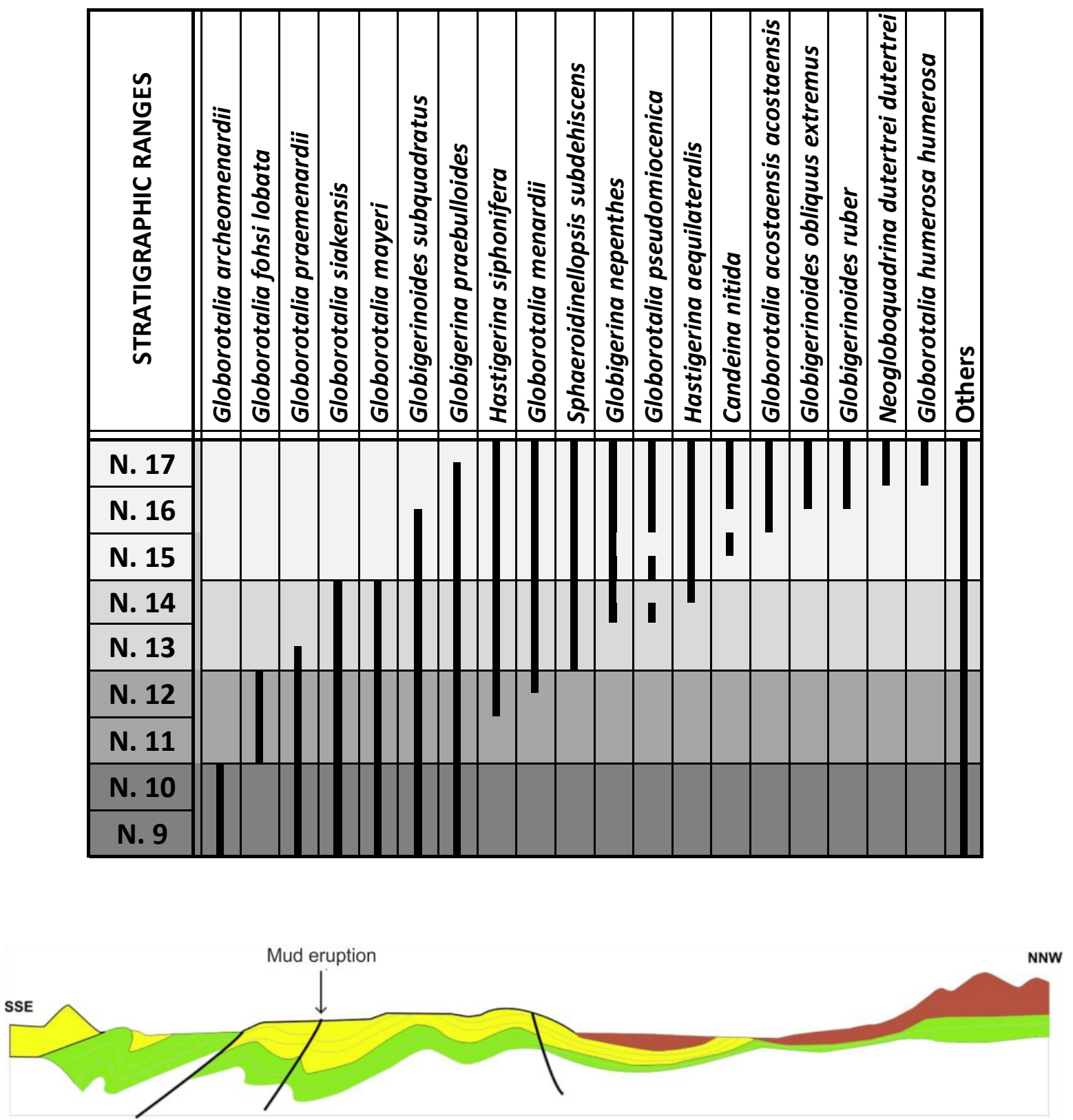

Figure 6. Profile of eruption system in escaping ejected mud to the surface (modification after Isnaniawardhani, et al., 2015b) Pemali Formation = green, Halang Formation = yellow, Quartenary Lahar Deposits $=$ brown. 


\section{CONCLUSIONS}

- A total of 84 foraminiferal species was identified in host rock. Forty-two species of them are planktic (genera Candeina, Catapsydrax Globigerina, Globigerinoides, Globoquadrina, Globorotalia, Hastigerina, Neogloboquadrina, Orbulina and Sphaerodinellopsis) and forty-two species (genera Amphistegina, Amphycorina, Anomalinella, Anomalinoides, Bolivina, Brizalina, Bulimina, Cassidulina, Cibicides, Dentalina, Duplella, Eggrella, Elphidium, Eponides, Fiscerinella, Fijinonion, Glandulina, Globocassidulina, Gyroidina, Hanzawaia, Heterolepa, Hyalinea, Hyperammina, Laevidentalina, Lenticulina, Martinotiella, Melonis, Missipina, Nodogenerina, Nodosaria, Nonion, Nummulites, Planulina, Pseudononion, Pyrgo, Quinqueloculina, Robulus, Rotalia, Sigmoilina, Stilostomella, Textularia and Uvigerina) are benthic.

- Planktic foraminifera assemblages contained in host rock reveals the age of Middle to Late Miocene (Zone N.11 to N.17). Based on benthic foraminifera, the rocks were deposited in outer neritic to bathyal influenced by turbidite mechanism.

- Materials ejected from subsurface are claystone to sandstone-size fragments, liquid, gas, and heat. The sedimentary rock fragments generally contain foraminifera. About $89.28 \%$ of foraminiferal species is recorded in the mud.

- Based on their stratigraphic ranges, planktic foraminifera represent four age-marker groups, there are: older than Zone N.10/Middle Miocene (indicated by the appearance of Globorotalia archeomenardii), ranges of Zone N.11 N.12/Middle Miocene (marked by the appearance of Globorotalia fohsi lobata and Globorotalia praemenardii), ranges of Zone N.13 - N.14/Middle Miocene (Globorotalia siakensis and Globorotalia mayeri), and ranges of Zone N.15 - N.17/Late Miocene (Globorotalia acostaensis acostaensis and Neogloboquadrina dutertrei dutertrei).
- Benthic foraminifera assemblages in mud samples can be grouped to outer neritic and bathyal typical groups.

- The similarity and mixing of foraminifera assemblages in mud samples indicate material erupted have originated from erosion and elution of base- and side-rocks of Pemali and Halang Formations deposited during Middle to Late Late Miocene. Fluid and gas outputs under excess pressure condition will move to the surface by carrying the material.

\section{ACKNOWLEDGEMENTS}

We thandked Rector of Padjadjaran University for the provision of funding to carry out this research through the Academic Leadership Grant (ALG) no 885/UN6.3.1/PL/2017. The authors wish to express their gratitude to the Faculty of Engineering Geology for the facilities to implement this research, including the participation of the students.

\section{REFERENCES}

Blow, W. H, 1979, The Cainozoic Globigerinida, Leiden E.J. Brill, 421 pp.

Bolli, H.M., Saunders, J.B, 1986. Oligocene to Holocene Low Latitude Planktic Foraminifera, in Bolli, H.M., Saunders, J.B., Perch Nielsen, K. (Eds). Plankton Stratigraphy, Cambridge University Press., 155-262.

Budhitrisna, T., 1986. Geological Map of the Tasikmalaya Quadrangle, Java, scale 1:100.000, Geological Research and Development Centre Bandung.

Davies, R. J., Brumm, M., Manga, M., Rubiandini, R., Swarbrick, R., Tingay, M., 2008. The east Java mud volcano (2006-present): an earthquake or drilling trigger, Earth and Planetary Science Letters 272 (3-4), 627-638.

Hochstein and Sudarman, 2010. Monitoring of LUSI mud volcano - a geo pressured system, Java Indonesia, Proceeding, World Geothermal Congress, Bali, Indonesia, 25-29 April 2010, 1-9.

Isnaniawardhani, V., Adhiperdana, B. G., Nurdradjat, 2015a. Biostratigrafi Endapan Turbidit Miosen di Daerah 
Ciniru, Kabupaten Kuningan, Pustaka Ilmiah Universitas Padjadjaran. repository.unpad.ac.id. Downloaded 15 February 2018.

Isnaniawardhani, V., Helmi, F., Muhammadsyah, F., 2015b. Stratigraphy and Structural Geology of Ciuyah Mud Volcanoes in Ciniru Area, West Java, International Journal of Science and Research, 4(4), 3223-3226.

Isnaniawardhani, V., Muhammadsyah, F., Haryanto, I., Natasya, N., Effendi, T. K., Putra, D. M., and Sulaksana, N., 2018. Geological Dinamic Modelling of Ciuyah Mud Eruption in Java, Indonesia, International Journal of GEOMATE, 14(44), unpublished results.

Istadi, B. P, Wibowo, H. T., Sunardi, E., Hadi, S., Sawolo, N., 2012. Mud Volcano and Its Evolution, Earth Sciences, Edt. Dar I., A., Intech, 375-433.

Kastowo and Suwarna, N., 1996. Geological Map of the Majenang Quadrangle, Java scale 1:100.000, Second Edition, Geological Research, and Development Centre Bandung.

Kumai, H., Yamamoto, H., 2007, Earthquake, the major trigger of mud volcanism at Sidoarjo, East Java, Proceeding of the International Geological Workshop on Sidoarjo Mud Volcano, Indonesian Agency for the Assessment and Application of Technology, Indonesian Association of Geologist, Indonesian Science Institute.

Manga, M., 2007. Did an earthquake trigger the May 2006 eruption of the LUSI mud volcano, EOS 88 (201), https://agupubs.onlinelibrary.wiley.com /doi/abs/10.1029/2007EO180009, downloaded 15 February 2018.

Mazzini, A., Nermoen, A., Krotkiewski, M., Podladchikov, Y.Y., Planke, S., Svensen, H., 2009. Strike-slip faulting as a trigger mechanism for overpressure release through piercement structures. The implication for the LUSI mud volcano, Indonesia. Marine and Petroleum Geology, 26, 1751-1765.

Mellors, R., Kilb, D., Aliyev, A., Glasanov, A., Yetirmishli, G., 2007. Correlations between earthquakes and large mud volcano eruptions, Journal of Geophysical Research, 112.

Milkov, A. V., 2000. Worldwide distribution of submarine volcanoes and associated gas hydrates, Marine Geology, 197, 29 - 42.

Muhamadsyah, F., Sunardi, E., Isnaniawardhani, V., 2012. The Characteristics of Geology in Ciuyah Mud Volcano Area (in Indon.), Bulletin of Scientific Contribution, 10(2), 59-76.

Nathan, S. A., Leckie, R. M. 2003. Miocene Planktonic Foraminiferal Biostratigraphy of Sites 1143 and 1146, ODP Leg 184, South China Sea: in Prell, W.L., Wang, P. Blum, P., Rea, D.K., Clemens, S.C. (Eds). Proceeding of the Ocean Drilling Program, Scientific Result,184, 1-43.

Pitt, A. M., Hutchinson, R. A., 1982. Hydrothermal changes related to earthquake activity at mud volcano, Yellowstone National Park, Wyoming, Journal of Geophysical Research 87, $2762-2766$.

Satyana A. H., and Asnidar, 2008. Mud Diapirs and Volcanoes in depressions of Java to Madura: Origins, Nature, and Implications to Petroleum System. Proceedings, Indonesian Petroleum Association (IPA), 32 nd Annual Convention \& Exhibition, IPA08-G139.

Sawolo, N., Sutriono, E., Istadi, B. P., Darmoyo, A.B., 2009. Mud Volcano triggering controversy: was it caused by drilling? Journal Marine and Petroleum Geology, 26, 1766-1784.

Walter, T. R., Wang, R., Luehr, B. G., Wassermann, J., Behr, Y., Parolai, S., Anggraini, A., Gunther, E., Sobiesiak, M., Grosser, H., Wetzel, H. U., Milkereit, C., Sri Brotopuspito, P.J.K., Harjadi, P., Zschau, J., 2007. The 26 May 1926 magnitude 6.4 Yogyakarta 
earthquake South of Mt. Merapi volcano: did lahar deposits amplify ground shaking and thus lead to the disaster, Geochemistry, Geophysics and Geosystem 9, Q05006, DOI: 10.1029/2007GC001810.

Van Marle, 1992, Eastern Indonesia Late Cenozoic Smaller Benthic Foraminifera, Royal Netherlands Academy, 328 pp. 